\title{
Influence of Technological Operations in the Dissolved Oxygen Content of Wines
}

\author{
Ana Catarino ${ }^{1}$, Sandra Alves ${ }^{2}$ and Helena Mira ${ }^{1 *}$ \\ 1. Polytechnic Institute of Santarém. Escola Superior Agrária de Santarém, Department of Food Technology, Biotechnology and \\ Nutrition, Quinta do Galinheiro-S. Pedro 2001-904, Santarém \\ 2. Esporão, S.A. Herdade do Esporão, 7200-999 Reguengos de Monsaraz
}

Received: February 10, 2014 / Accepted: February 28, 2014 / Published: April 25, 2014.

\begin{abstract}
Oxygen plays a crucial role in oenology. The oxygen leads to changes in the chemical and sensory profile of wines. On one hand, the impact of moderate oxygen exposure of red wine has a positive effect in its colour, aromatic bouquet and mouth-feel properties. On the other hand, oxygen has a negative effect on white wine's quality, as well as the sensory and compositional levels. The purpose of this study was to quantify the dissolved oxygen in red and white wine, during different cellar operations such as racking, tartaric stabilization, filtering and bottling. The techniques that contribute most to the enrichment of oxygen in wine are: cold tartaric stabilization $(2.29 \mathrm{mg} / \mathrm{L}$, white wines), bottling $(1.38 \mathrm{mg} / \mathrm{L}$ red wines and $1.11 \mathrm{mg} / \mathrm{L}$ white wines $)$ and bag-in-box filling ( $2.47 \mathrm{mg} / \mathrm{L}$ red wines; $2.22 \mathrm{mg} / \mathrm{L}$ white wines). After identifying the most critical technical operations in wine making, preventive and corrective measures had to be taken to reduce the dissolved oxygen content of wines, as well as preventing their depreciation.
\end{abstract}

Key words: Wine, oxygen, oxidation, dissolution.

\section{Introduction}

Oxygen exists as a gaseous element representing $20.9 \%$ of earth atmosphere, under standard temperature and pressure, and it is indispensable for the majority of the living organisms.

The oxygen plays a crucial role in enology. Louis [1] had already noted that oxygen could be a great enemy of wine or wine making.

Oxygen can dissolve in wine at several stages during winemaking, bottling and aging. It plays a beneficial role during the winemaking process: in promoting yeast multiplication, in the maturation and stabilization of wine colour, in the removal of the reduced compounds taste, and attenuation of the vegetable character, etc.. However, when the wine is exposed to excessive amounts of oxygen, it can have negative effects such as the promotion of the growth

*Corresponding author: Helena Mira, Professor Adjunto, research fields: wine, fruits and vegetables, postharvest. E-mail: helena.mira@esa.ipsantarem.pt. of unfavourable microorganisms in wine (acetic bacteria, Brettanomyces), the degradation of colour and the production of organoleptic defects, etc..

The oxidation in white wine causes important sensory alterations in the colour and the aroma. The browning is characterized by progressive darkening which can be globally characterized by absorbance at $420 \mathrm{~nm}$ [2]. The oxygen induces a loss of freshness and fruitiness, and develops an unpleasant oxidized character, which is generally described as non-desirable flavours of "honey-like", "boiled-potato", "cooked vegetable", "farm-feed" and "woody-like" [3-7].

Phenolics compounds are the main oxidation substracts. Various researchers have studied the impact of oxygen exposure on the polyphenolic composition of red wines [8-10]. Some controlled and continuous $\mathrm{O}_{2}$ is introduced into red wine (micro-oxygenation) to improve wine quality, such as colour stability and intensity, softening of astringent 
tannins, and decreases reductive and vegetative aromas.

During winemaking, the different unit operations may integrate some oxygen from the atmosphere into the wine. The operations such as pumping, transport, racking, centrifugation, stabilization, filtration and bottling have been studied by various authors [11-17].

Various researchers have monitored the dissolved oxygen of wine at bottling and during storage and the influence of packaging in wine conservation $[3,6,10$, 13, 14, 17-19].

The Esporão SA is one of the biggest wineries in Portugal. The purpose of this study was to quantify the dissolved oxygen in red and white wine, during different oenological treatments such as racking, tartaric stabilization, filtering and bottling, to identify the critical points (the unit operations) that contribute most to the integration of oxygen in wine and to establish preventive and corrective measures.

\section{Experiments}

\subsection{Wines}

The white or red wines analyzed were produced during 2010 vintage in Esporão S.A. (Alentejo) from different varieties (Arinto, Antão Vaz, Perrum; Moreto, Trincadeira e Castelão, Touriga Nacional, Cabernet Sauvignon, among other). All wines were obtained following the usual winemaking processes.

\subsection{Wine Treatments}

Red and white wines were submitted to specific oenological treatments (Table 1) with systems, equipment and procedures commonly used in winery. The increase of dissolved oxygen $\left(O_{\text {diss }}\right)$ was calculated as the difference between the oxygen concentration measured before $\left(O_{b e f}\right)$ and immediately after $\left(O_{a f t}\right)$ each treatment $\left(O_{\text {diss }}=O_{a f t}-O_{b e f}\right)$.

\subsection{Measurement of Dissolved Oxygen}

The measurement of dissolved oxygen was carried out using a portable oxímeter Crison OXI $45 \mathrm{P}$.

\subsection{Statistical Procedures}

(1) Data of the increase of dissolved oxygen are expressed as the average and standard deviation of measurements performed for the different wines.

(2) The influence of oenological treatments was analyzed by non-parametric procedures by the paired-samples $T$-test (before and after treatment), with the Wilcoxon signed ranks test, using the SPSS statistics software (Version 17.0).

\section{Results and Discussion}

The level of dissolved oxygen at a given time in the wine depends on the dissolution and consumption kinetics. When applied to a wine movement (pumping, filling and stirring) the kinetics of oxygen dissolution is higher than the consumption by the wine's compounds. Dissolved oxygen reacts with the constituents of the wine and disappears gradually, reaching very low levels.

After racking, the evolution of dissolved oxygen consumption in the wine was monitored over time (Fig. 1). It was found that the kinetics of consumption varied depending on the type of wine, having been noted that the white wine kinetics were slower than the red wines kinetics. Red wines consume oxygen faster than white wines because of its constitution of phenolic compounds. In the case of red wines, in just four days phenolic compounds consumed more than half of dissolved oxygen. For white wines, it took more than 30 days. Increasing temperature increases the kinetics of dissolved oxygen consumption.

The monitoring of oxygen concentrations before and after specific oenological treatments provided data on the levels of enrichment of the winery and its variability.

Statistical analysis performed using nonparametric paired samples revealed that the enrichment in dissolved oxygen is significant for all operations performed (Table 2).

The increase of dissolved oxygen for each treatment is shown in Table 3. 
Table 1 Description of oenological treatments.

\begin{tabular}{llll}
\hline White wine & $n$ & Red wine & $n$ \\
\hline Protein stabilization (bentonite addition) & 4 & Racking (bottom-bottom) & 110 \\
Continuous tartaric stabilization (cooling method) & 12 & Tartaric stabilization (metatartaric acid addition) & 12 \\
Filtration (membrane cartridges, nominal porosity 1-0.45 $\mu \mathrm{m})$ & 29 & Tangential filtration & 47 \\
Bottling (glass bottles) & 28 & Bottling (glass bottles) & 147 \\
Packaging (bag-in-box, 5 L) & 9 & Packaging (bag-in-box, 5 L) & 26 \\
\hline
\end{tabular}

$n=$ number of analysed wines.

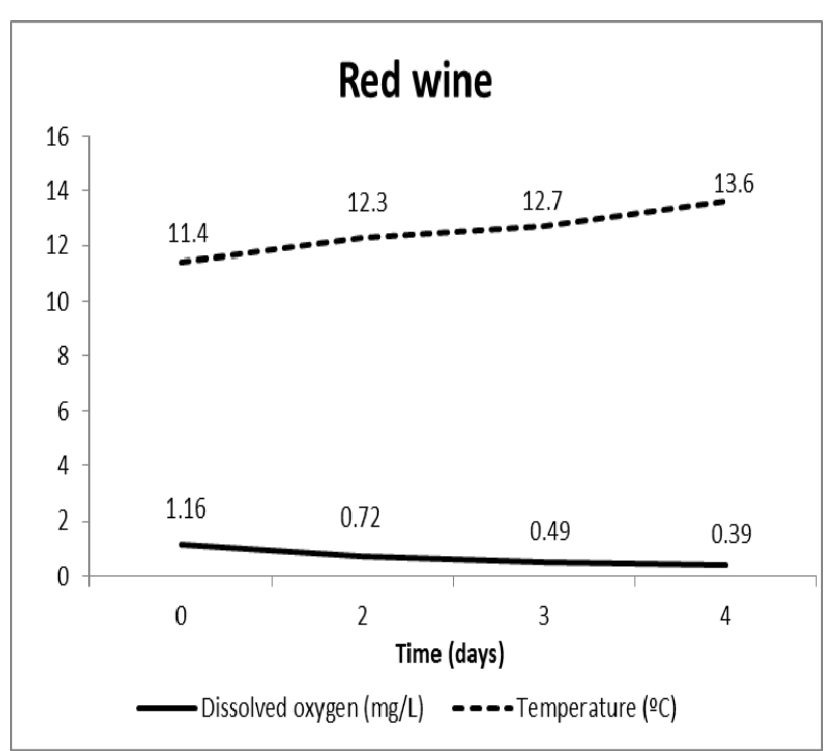

(a)

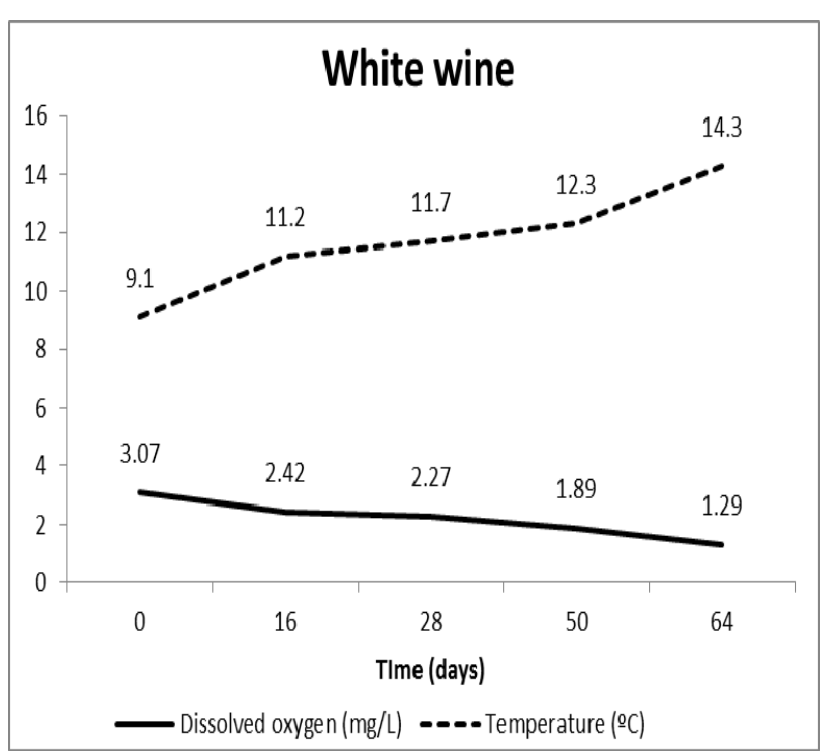

(b)

Fig. 1 Evolution of dissolved $\mathrm{O}_{2}$ in wine after racking: (a) red wine, (b) white wine.

Table 2 The average content of dissolved oxygen (mg/L), before and after each oenological treatment and $p$-value of Wilcoxon signed ranks test.

\begin{tabular}{lllll}
\hline & Oenological treatment & Before treatment & After treatment & $p$-value (Wilcoxon test) \\
\hline \multirow{6}{*}{ Red wine } & Racking & $0.19 \pm 0.12$ & $0.65 \pm 0.34$ & 0.000 \\
& Tartaric stabilization & $0.28 \pm 0.25$ & $0.38 \pm 0.26$ & 0.002 \\
& Tangential filtration & $0.14 \pm 0.49$ & $0.40 \pm 0.33$ & 0.000 \\
& Bottling (glass bottles) & $0.49 \pm 0.42$ & $1.87 \pm 0.93$ & 0.000 \\
& Packaging (bag-in-box) & $0.98 \pm 0.28$ & $3.45 \pm 0.86$ & 0.000 \\
\hline \multirow{3}{*}{ White wine } & Protein stabilization & $1.22 \pm 0.85$ & $1.35 \pm 0.89$ & 0.042 \\
& Cold tartaric stabilization & $0.60 \pm 0.37$ & $2.89 \pm 1.80$ & 0.008 \\
& Filtration (membrane cartridges) & $0.20 \pm 0.17$ & $0.71 \pm 0.16$ & 0.000 \\
& Bottling (glass bottles) & $0.67 \pm 0.24$ & $1.78 \pm 0.42$ & 0.000 \\
& Packaging (bag-in-box) & $0.65 \pm 0.22$ & $2.87 \pm 0.96$ & 0.008 \\
\hline
\end{tabular}

Racking increased the dissolved oxygen content by on average of $0.46 \mathrm{mg} / \mathrm{L}$, exceeding that observed $[11,15]$. The oxygen enrichment in the racking occurs essentially at the beginning and end of the transfer, due to the dissolution of air contained in the pipes and tanks. The racking should be performed bottom to bottom of the tanks, and it uses inert gas in the pipes and tanks before starting the transfer process $[13,14]$.

For the tartaric stabilization of red wine, metatartaric acid was added just prior to bottling. The homogenization of the wine was achieved with nitrogen. The addition of the metatartic acid leads to an increase of $0.10 \mathrm{mg} / \mathrm{L}$ of dissolved oxygen, which is a reduced amount when compared to the cold tartaric stabilization. 
Table 3 Increase of dissolved oxygen $(\mathrm{mg} / \mathrm{L})$ in each oenological treatment.

\begin{tabular}{lll}
\hline & Oenological treatment & $\mathrm{O}_{2} \mathrm{D}(\mathrm{mg} / \mathrm{L})(\mathrm{mean} \pm$ standard deviation $)$ \\
\hline \multirow{4}{*}{ Red wine } & Racking & $0.46 \pm 0.31(n=110)$ \\
& Tartaric stabilization & $0.10 \pm 0.06(n=12)$ \\
& Tangential filtration & $0.26 \pm 0.30(n=47)$ \\
& Bottling (glass bottles) & $1.38 \pm 0.49(n=147)$ \\
& Packaging (bag-in-box) & $2.47 \pm 0.93(n=26)$ \\
\hline \multirow{3}{*}{ White wine } & Protein stabilization & $0.13 \pm 0.05(n=4)$ \\
& Cold tartaric stabilization & $2.29 \pm 1.78(n=12)$ \\
& Filtration (membrane cartridges) & $0.51 \pm 0.18(n=29)$ \\
& Bottling (glass bottles) & $1.11 \pm 0.47(n=28)$ \\
\hline
\end{tabular}

The important enrichment that occurred during cold tartaric stabilization of the white wines was on average $2.21 \mathrm{mg} / \mathrm{L}$ (Table 3 ), and these results are consistent with data found by other authors $[12,13$, 15]. The sharp temperature drop caused an increase in the oxygen dissolution rate, therefore, it is important to protect the wine from the oxygen in the operation.

The protein stabilization of white wine by the addition of bentonite showed a small enrichment in dissolved oxygen. It was noted that this operation did not contribute a lot to the increase of dissolved oxygen in the wine, similar to what was observed for the tangential filtration of red wines, in which the dissolved oxygen was lower than that reported by Vidal et al. [11, 13].

The filtration by membrane cartridges increased the dissolved oxygen content mainly due to air inlets in the circuit, in particular through the pipe connections, the pump and filter body. The dissolved oxygen in wine is higher than that reported in Refs. [11, 13, 15], these authors noted average values of $0.10 \mathrm{mg} / \mathrm{L}$ and $0.06 \mathrm{mg} / \mathrm{L}$, respectively. This is due to the length and the diameter of the tubing as well as the turbulent flow, which influences the kinetics of oxygen dissolution.

Unlike the results of Vidal et al. [13, 14], filling in BIB (bag-in-box) has contributed to a greater enrichment in dissolved oxygen than bottling. This is due to a problem with an inertized filling machine used to fill BIB containers. To reduce the risk of wine oxidation in $\mathrm{BIB}$, the concentration of $\mathrm{SO}_{2}$ was increased up to a maximum of $50 \mathrm{mg} / \mathrm{L},(1 \mathrm{mg} / \mathrm{L}$ oxygen oxidizes $4 \mathrm{mg} / \mathrm{L} \mathrm{SO}_{2}$ ), so that the $\mathrm{SO}_{2}$ protects the wine from oxidation and browning [19].

Bottles were filled using a filling machine inertized with nitrogen. However, this operation was responsible for some increase in dissolved oxygen content, both in white wine and in red wine. These results are in agreement with those previously described $[13,14,18]$. The filling is the main critical point for wine enrichment in oxygen.

\section{Conclusions}

The rationalization of the operating conditions and the reasonable use of neutral gases, especially at the beginning and the end of operation, are necessary to control and decrease significantly the oxygen pick up in all the operations.

The most important enrichments occur especially during the operations of cold tartaric stabilization and during the bottling and packaging, especially if no protection is taken to protect the wine from the oxygen in the air.

Controlling the oxygen ingress during filling (bottle or BIB) is an important way of improving the quality and the shelf-life of wine.

\section{Acknowledgments}

The authors thank Esporão S. A. for the means for carrying out this work. 


\section{References}

[1] Pasteur, L. Studies on Wine: Its Diseases, Causes, New Methods to Conserve and for Aging; Printed by Royale: Paris, 1873; p 264.

[2] Singleton, V. L. Oxygen with Phenols and Related Reactions in Musts, Wines and Model Systems: Observations and Practical Implications. American Journal of Enology and Viticulture 1987, 38, 69-77.

[3] Escudero, A.; Asensio, E.; Cacho, J.; Ferreira, V. Sensory and Chemical Changes of Young White Wines Stored under Oxygen as Assessment of the Role Played by Aldehydes and Some Other Important Odorants. Food Chemistry 2002, 77, 325-331.

[4] Silva, F. A. C.; Guedes, P. P.; Rodrigues, P.; Hogg, T. Kinetics of Oxidative Degradation of White Wines and How They Are Affected by Selected Technological Parameters. Journal of Agricultural and Food Chemistry 2002, 50, 5919-5924.

[5] Silva, F. A. C.; Hogg, T.; Guedes, P. P. Identification of Key Odorants Related to the Typical Aroma of Oxidation-Spoiled White Wines. Journal of Agricultural and Food Chemistry 2003, 51, 1377-1381.

[6] Lopes, P.; Silva, M. A.; Pons, A.; Tominaga, T.; Lavigne, V.; Saucier, C.; et al. Impact of Oxygen Dissolved at Bottling and Transmitted through Closures on the Composition and Sensory Properties of a Sauvignon Blanc Wine during Bottle Storage. Journal of Agricultural and Food Chemistry 2009, 57, 10261-10270.

[7] Karbowiak, T.; Gougeon, R. D.; Alinc, J. B.; Brachais, L.; Debeaufort, F.; Voilley, A.; et al. Wine Oxidation and the Role of Cork. Critical Reviews in Food Sciences and Nutrition 2010, 50, 20-52.

[8] Atanasova, V.; Fulcrand, H.; Cheynier, V.; Moutounet, M. Effect of Oxygenation on Polyphenol Changes Occuring in the Course of Wine-Making. Analytica Chimica Acta 2002, 458, 15-27.

[9] Toit, W. J.; Marais, J.; Pretorius, I. S.; Toir, M. Oxygen in Must and Wine: A Review. South African Journal of Enology and Viticulture 2006, 27(1), 76-91.

[10] Wirth, J.; Morel-Salmi, C.; Souquet, J. M.; Dieval, J. B.;
Aagaard, O.; Vidal, S.; et al. The Impact of Oxygen Exposure before and after Bottling on the Polyphenolic Composition of Red Wines. Food Chemistry 2010, 123, 107-116.

[11] Vidal, J. C.; Dufourcq, T.; Boulet, J. C.; Moutounet, M. Oxygen Contributions during Treatments of the Wines Assessment of the Observations on Site 1. French Review of Oenology 2001, 190, 24-31.

[12] Vidal, J. C.; Boulet, J. C.; Moutounet, M. Oxygen Contributions during Treatments of the Wines Assessment of the Observations on Site 2. French Review of Oenology 2003, 201, 32-38.

[13] Vidal, J. C.; Boulet, J. C.; Moutounet, M. Oxygen Contributions during Treatments of the Wines Assessment of the Observations on Site 3. French Review of Oenology 2004, 205, 25-33.

[14] Vidal, J. C.; Boulet, J. C.; Moutounet, M. Comparison of Methods for Measuring Oxygen in the Headspace of a Bottle of Wine. Journal International des Sciences de la Vigne et du Vin 2004, 38(3), 191-200.

[15] Castellari, M.; Simonato, B.; Tornielli, G. B.; Spinelli, P.; Ferrarini, R. Effects of Different Enological Treatments on Dissolved Oxygen in Wines. Italian Journal of Food Science 2004, 16(3), 387-396.

[16] Valade, M.; Tribaut-Sohier, I.; Bunner, D.; Pierlot, C.; Moncomble, D.; Tusseau, D. Oxygen Contributions in Wine Making and Their Impacts on the Wines-The Particular Case of Champagne 1. French Review of Oenology 2006, 221, 1-8.

[17] Valade, M.; Tribaut-Sohier, I.; Bunner, D.; Laurent, M.; Moncomble, D.; Tusseau, D. Oxygen Contributions in Wine Making and Their Impacts on the Wines-The Particular Case of Champagne 2. French Review of Oenology 2007, 222, 17-28.

[18] Vidal, J. C.; Moutounet, M. Monitoring of Oxygen in the Gas and Liquid Phases of Bottles of Wine at Bottling and during Storage. Journal International des Sciences de la Vigne et du Vin 2006, 40(1), 35-45.

[19] Ghidossi, R.; Poupot, C.; Thibon, C.; Pons, A.; Darriet, P.; Riquier, L.; et al. The Influence of Packaging in Wine Conservation. Food Control 2012, 23(2), 302-311. 